\title{
Analisis Faktor - Faktor yang Mempengaruhi Nilai Cash Holding Pada Perusahaan Sektor Industri Konsumsi
}

\author{
Mhd. Hafiz Maulana ${ }^{1}$, Monica Cheria ${ }^{2}$, Connie Halim ${ }^{3}$, Wilfrida Windra Sari Gea ${ }^{4}$, \\ H.Adam Afiezan ${ }^{*}$ \\ Universitas Prima Indonesia \\ hafizmaulana1811@gmail.com, monicacheria08@gmail.com, conniehalim12@gmail.com, \\ wilfridagea@gmail.com, adamafiezan@unprimdn.ac.id
}

*Corresponding Author

Diajukan : 21 September 2021

Disetujui : 4 Oktober 2021

Dipublikasi : : 1 Januari 2021

\section{ABSTRACT}

The consumption industry is a type of business that is developing quite rapidly in Indonesia which results in quite tight competition in the business industry in Indonesia so that it requires business people to be able to run their business and maintain their existence. This study intends to examine the effect of cash flow, growth opportunity, leverage, net profit/loss on cash holding in consumption industry companies listed on the Indonesia Stock Exchange for the 2017 2019 period. The research uses descriptive quantitative methods. The data used is secondary data obtained from the IDX through the https://www.idx.co.id site and obtained a sample of 36 companies that meet the criteria. The data analysis techniques used are: classical assumption test, multiple linear regression and hypothesis testing which includes $t$ test and $f$ test. The conclusion obtained from this study is that cash flow has a positive and significant effect on cash holding, leverage has a negative and significant effect on cash holding, growth opportunity, and net profit/loss has no and no significant effect on cash holding. Based on the coefficient of determination test, it was found that the dependent variable in this study was influenced by all independent variables as much as $34.7 \%$ and the remaining $65.3 \%$ was influenced by other variables apart from this study.

Keywords: Cash Flow, Cash Holding, Growth Opportunity, Leverage, Net Profit / Loss

\section{PENDAHULUAN}

Perindustrian konsumsi merupakan jenis usaha yang sedang berkembang cukup laju di Indonesia yang mengakibatkan persaingan yang cukup ketat dalam dunia bisnis di Indonesia sehingga, menuntut para pelaku bisnis untuk dapat menjalankan bisnisnya maupun mempertahankan eksistensinya.(Kariyoto, 2018) menyatakan bahwa beberapa perusahaan yang mengalami kasus bangkrut disebabkan oleh adanya masalah keuangan. Adapun strategi yang perlu dilakukan agar dapat menjalankan dan mempertahankan bisnis, yaitu pengelolaan aktiva seperti kas.

Tabel 1. Fenomena Penelitian (Disajikan dalam jutaan rupiah)

\begin{tabular}{|c|c|r|r|r|r|r|}
\hline $\begin{array}{c}\text { Kode } \\
\text { Emiten }\end{array}$ & Tahun & Cash Flow & $\begin{array}{c}\text { Growth } \\
\text { Opportunity }\end{array}$ & \multicolumn{1}{c|}{ Leverage } & Net Profit & $\begin{array}{c}\text { Cash } \\
\text { Holding }\end{array}$ \\
\hline \multirow{2}{*}{ GGRM } & 2017 & 11.237 .253 & 83.305 .925 & 24.572 .266 & 7.755 .347 & 2.329 .179 \\
\cline { 2 - 7 } & 2018 & 11.156 .804 & 95.707 .663 & 23.963 .934 & 7.793 .068 & 2.034 .169 \\
\cline { 2 - 7 } & 2019 & 15.073 .090 & 110.523 .819 & 27.716 .516 & 10.880 .704 & 3.571 .886 \\
\hline \multirow{2}{*}{ HMSP } & 2017 & 16.894 .806 & 99.091 .484 & 9.028 .078 & 12.670 .534 & 7.501 .737 \\
\hline
\end{tabular}


Owner: Riset \& Jurnal Akuntansi

e-ISSN : 2548-9224 |p-ISSN : 2548-7507

Volume xx Nomor xx, Bulan Tahun

DOI : https://doi.org/10.33395/owner.xxx.xxx

\begin{tabular}{|c|r|r|r|r|r|r|}
\hline & 2018 & 17.961 .269 & 106.741 .891 & 11.244 .167 & 13.538 .418 & 15.516 .439 \\
\cline { 2 - 7 } & 2019 & 18.259 .423 & 106.055 .176 & 15.223 .076 & 13.721 .513 & 18.820 .695 \\
\hline \multirow{3}{*}{ ICBP } & 2017 & 3.543 .173 & 35.606 .593 & 11.295 .184 & 3.543 .173 & 8.796 .690 \\
\cline { 2 - 7 } & 2018 & 4.658 .781 & 38.413 .407 & 11.660 .003 & 4.658 .781 & 4.726 .822 \\
\cline { 2 - 7 } & 2019 & 5.360 .029 & 42.296 .703 & 12.038 .210 & 5.360 .029 & 8.359 .164 \\
\hline
\end{tabular}

Sumber : $\underline{\text { www.idx.co.id }}$

PT Gudang Garam Tbk, dimana nilai growth opportunity yang dimiliki pada tahun 20172018 mengalami kenaikan sebesar Rp 12.401.738.000.000 atau sebesar 14.8\% sedangkan cash holding di periode 2017-2018 menyusut sebanyak Rp 295.010.000.000 atau 12.6\%.

Pada perusahaan PT Hanjaya Mandala Sampoerna Tbk, nilai growth opportunity pada tahun 2018-2019 mengalami penurunan sebesar Rp 686.715.000.000 atau sebesar $0.64 \%$ sedangkan nilai cash holding mengalami kenaikan sebesar $21.29 \%$ atau setara dengan $\mathrm{Rp}$ 3.304.256.000.000.

PT Indofood Sukses Makmur Tbk, cash flow pada periode 2017-2018 terjadi peningkatan sebanyak Rp 1.115.608.000.000 atau 31.48\%, leverage pada tahun 2017-2018 terjadi kenaikan sebanyak Rp 364.819.000.000 atau sebanyak 3.22\%, dan nilai net profit di periode 2017-2018 terjadi kenaikan sebanyak Rp 1.115.608.000.000 atau sebanyak $31.48 \%$ sedangkan terjadi penurunan pada nilai cash holding tahun 2017-2018 sebesar Rp 4.069.868.000.000 atau 46.26\%.

Berdasarkan tabel fenomena yang terjadi bisa diartikan bahwa penurunan maupun peningkatan nilai cash holding disebabkan cash flow, leverage, growth opportunity, dan net profit/loss yang berfluktuasi sehingga dapat mempengaruhi besar kecilnya cash holding suatu perusahaan.

Salah satu studi kasus yang terjadi di perusahaan PT Dua Putra Utama Makmur Tbk dimana terjadi kenaikan penjualan serta laba, akan tetapi kas perusahaan pada caturwulan I tahun 2017 mengalami minus sebesar Rp $21 \mathrm{M}$, sehingga dapat menyebabkan perusahaan mencari dana dari pihak eksternal. Dari kasus ini, dapat disimpulkan bahwa terdapat kurangnya control terhadap cash holding perusahaan sehingga dapat menyebabkan minusnya nilai cash holding sementara penjualan dan laba mengalami peningkatan.

Penelitian ini bertujuan guna melanjutkan penelitian sebelumnya yang diteliti oleh (Hasana, 2019) dengan judul "Analisis Pengaruh Cash Conversion Cycle, Modal Kerja Bersih, Growth Opportunity, dan Capital Expenditure terhadap Cash Holding", dimana Hasana memilih bidang industri property/real estate yang tercatat di IDX tahun 2016 - 2018. Berbeda dengan riset yang dilakukan oleh Hasana, penulis menetapkan objek penelitian ini dengan sektor consumer goods yang terdaftar di IDX tahun 2017 - 2019. Selain objek dan tahun penelitian yang berbeda, penulis juga mengurangi variabel modal kerja bersih, cash conversion cycle, dan capital expenditure. Penulis menambahkan tiga variabel baru yakni cash flow, leverage, dan net profit/loss.

\section{Hipotesis Penelitian}

H1 : Cash flow berpengaruh positif terhadap cash holding

$\mathrm{H} 2 \quad$ : Growth opportunity berpengaruh positif terhadap cash holding

H3 : Leverage berpengaruh positif terhadap cash holding

H4 : Net profit/loss berpengaruh positif terhadap cash holding

H5 : Cash flow, growth opportunity, leverage, dan net profit/loss berpengaruh secara simultan terhadap cash holding

\section{Pengaruh Cash Flow terhadap Cash Holding}

\section{STUDI LITERATUR}

Menurut (Powell, 2018) bisnis dengan peluang investasi disarankan untuk menyimpan kas dengan jumlah besar dalam menghadapi ketidakpastian aliran dana di periode mendatang untuk membiayai kebutuhan investasi perusahaan. Dengan ini dapat dinyatakan bahwa cash flow 
berpengaruh positif terhadap cash holding, diperkuat oleh hasil penelitian dari (Maya Sari \& Ardian, 2019) dan (Sethi \& Swain, 2019).

\section{Pengaruh Growth Opportunity terhadap Cash Holding}

(Simanjuntak \& Wahyudi, 2020) menyatakan tingkat peluang pertumbuhan usaha akan berbanding lurus dengan dana yang ditahan, karena perusahaan yang mengalami kenaikan penjualan akan memiliki kesempatan yang lebih besar dalam menyimpan kas lebih maksimal. Dengan ini dapat dinyatakan bahwa growth opportunity berpengaruh positif terhadap cash holding, diperkuat oleh hasil penelitian yang dilakukan (Shabbir, Haider Hashmi, \& Mujtaba Chaudhary, 2016) dan (Sari \& Hastuti, 2020).

\section{Pengaruh Leverage terhadap Cash Holding}

(Angelia \& Dwimulyani, 2019) menyimpulkan cash holding dipengaruhi oleh leverage perusahaan karena ketika perusahaan membayar kewajibannya, maka akan berpengaruh terhadap kas perusahaan. Dalam penelitian (Alicia, Putra, Fortuna, Felin, \& Purba, 2020) menyebutkan leverage berpengaruh positif terhadap cash holding.

\section{Pengaruh Net Profit/Loss terhadap Cash Holding}

(Humendru \& Pangaribuan, 2018), perusahaan yang memperoleh laba akan cenderung menahan/menyimpan dana dengan jumlah cukup besar, karena tidak hanya mempertimbangkan apa yang akan didapat, perusahaan juga harus dapat memperkirakan beban yang dihasilkan dari tindakan itu. Dalam penelitian (Humendru \& Pangaribuan, 2018) menyebutkan net profit/loss memiliki pengaruh positif terhadap cash holding.

\section{METODE}

Bentuk penelitian yang digunakan ialah kausal kontributif yakni untuk melihat bagaimana pengaruh cash flow, growth opportunity, net profit/loss, dan leverage terhadap cash holding. Data sekunder ditetapkan sebagai metode pengumpulan data pada penelitian ini. (Sugiyono, 2017, p. 137) mengemukakan bahwa data sekunder yaitu data tidak diperoleh dari sumber secara langsung, melainkan melalui pihak lain, misalnya dokumen, orang lain, situs resmi, dan lain sebagainya. Penelitian ini memperoleh sumber data melalui https://www.idx.co.id dan diolah menggunakan software SPSS.

\section{Populasi dan Sampel}

Penulis menetapkan sektor consumer goods yang tercatat di IDX periode 2017-2019 sebagai populasi pada penelitian ini. Metode pengambilan sampel yang peneliti pakai ialah purposive sampling, dimana peneliti menetapkan kriteria untuk memilah yang dijadikan sebagai data sampel.

Tabel 2. Pengambilan Sampel

\begin{tabular}{|l|l|c|}
\hline No & Kriteria Pengambilan Sampel & $\begin{array}{c}\text { Jumlah } \\
\text { Sampel }\end{array}$ \\
\hline 1 & Perusahaan sektor industri konsumsi yang terdaftar di BEI periode 2017 - 2019 & 54 \\
\hline 2 & $\begin{array}{l}\text { Perusahaan sektor industri konsumsi yang tidak mempublikasikan laporan } \\
\text { keuangan tahunan secara berturut - turut selama periode 2017-2019 }\end{array}$ & $(18)$ \\
\hline & Jumlah sampel yang digunakan & 36 \\
\hline & Jumlah pengamatan (36x3) & 108 \\
\hline
\end{tabular}

Sumber : idx.co.id

Tabel 3. Definisi Operasional Variabel

\begin{tabular}{|l|c|c|c|c|}
\hline No & Variabel & Definisi Operasional & Indikator & Skala \\
\hline
\end{tabular}


Owner: Riset \& Jurnal Akuntansi

e-ISSN : 2548-9224 |p-ISSN : 2548-7507

Volume xx Nomor xx, Bulan Tahun

DOI : https://doi.org/10.33395/owner.xxx.xxx

\begin{tabular}{|c|c|c|c|c|}
\hline 1 & $\begin{array}{l}\text { Cash Flow } \\
\text { (X1) }\end{array}$ & $\begin{array}{l}\text { Cash flow ialah arus kas } \\
\text { keluar dan masuk suatu } \\
\text { industri/perusahaan. } \\
\text { (Kartikahardi, Sinaga, } \\
\text { Wahyuni, Siregar, \& } \\
\text { Syamsul, 2017). }\end{array}$ & $\begin{array}{l}\text { Cash Flow: } \\
\qquad \frac{\text { EBIT }+ \text { Depresiasi }}{\text { Aktiva Bersih }} \\
\text { (Gunawan, 2016) }\end{array}$ & Rasio \\
\hline 2 & $\begin{array}{l}\text { Growth } \\
\text { Opportunity } \\
\text { (X2) }\end{array}$ & $\begin{array}{l}\text { Growth opportunity pada } \\
\text { umumnya diartikan sebagai } \\
\text { kapabilitas manajemen } \\
\text { usaha untuk ekspansi } \\
\text { bisnisnya. } \\
\text { (Andika, 2017) }\end{array}$ & $\begin{array}{l}\text { Growth Opportunity: } \\
\frac{\text { Total Penjualan } t-\text { Total Penjualan } t-1}{\text { Total Penjualan } t-1} \\
\text { (Sari \& Hastuti, 2020) }\end{array}$ & Rasio \\
\hline 3 & $\begin{array}{l}\text { Leverage } \\
\text { (X3) }\end{array}$ & $\begin{array}{lr}\text { Leverage } & \text { menunjukkan } \\
\text { suatu } & \text { kemampuan } \\
\text { perusahaan } & \text { dalam } \\
\text { mengelola } & \text { aktiva } \\
\text { perusahaan } & \text { untuk } \\
\text { menaikkan } & \text { pendapatan } \\
\text { perusahaannya. } & \end{array}$ & $\begin{array}{l}\text { Leverage: } \\
\qquad \frac{\text { Total Hutang }}{\text { Total Aset }} \\
\text { (Alicia et al., 2020) }\end{array}$ & Rasio \\
\hline 4 & $\begin{array}{l}\text { Net Profit } \\
\quad \text { /Loss } \\
\quad(\mathrm{X} 4)\end{array}$ & $\begin{array}{l}\text { Net profit/loss merupakan } \\
\text { kerugian atau keuntungan } \\
\text { dalam suatu periode usaha. } \\
\text { Variabel ini dinyatakan } \\
\text { sebagai variabel dummy } \\
\text { dengan ketentuan } 1 \text { dan } 0 . \\
\text { (Humendru \& Pangaribuan, } \\
2018 \text { ) }\end{array}$ & $\begin{array}{l}\text { Net Profit/Loss : } \\
\text { Ketentuan } \\
\quad(\text { Laba }=1, \text { Rugi }=0) \\
\text { (Humendru \& Pangaribuan, 2018) }\end{array}$ & Nominal \\
\hline 5 & $\begin{array}{l}\text { Cash } \\
\text { Holding } \\
\quad \text { (Y) }\end{array}$ & $\begin{array}{l}\text { Cash holding ialah } \\
\text { skejumlah dana yang dapat } \\
\text { dikeluarkan dengan lancar } \\
\text { guna memenuhi aktivitas } \\
\text { operasional perusahaan. } \\
\text { (Hasana, 2019) }\end{array}$ & $\begin{array}{l}\text { Cash Holding: } \\
\quad \frac{\text { Kas dan setara kas }}{\text { Total Aset }} \\
\text { (Hengsaputri \& Bangun, 2020) }\end{array}$ & Rasio \\
\hline
\end{tabular}

\section{Uji Asumsi Klasik}

Syarat yang wajib terpenuhi dalam analisis regresi linear berganda untuk mengecek sampel yang diteliti telah terhindar dari gangguan yaitu uji asumsi klasik, dengan melakukan beberapa pengujian seperti uji normalitas, multikolinieritas, heteroskedastisitas, dan autokorelasi.

Uji normalitas melalui pengujian Kolmogorov-Smirnov untuk menilai data telah berdistribusi normal (Ghozali, 2016). Data residual dinyatakan terdistribusi dengan normal jika mempunyai signifikan >0,05 (Hantono, 2017, p. 58)

Uji multikolinieritas dilaksanakan guna melihat hubungan yang terjadi di antara variabel bebas. Data dikatakan terbebas dari gejala multikolinieritas bila nilai VIF $\leq 10$ \& tolerance $\geq 0,10$ (Hantono, 2017, p. 66)

Uji heteroskedastisitas ini digunakan untuk menilai suatu model regresi linear adanya perbedaan varian pada residual antar pengamatan. Ketentuan data terbebas oleh gejala heteroskedastisitas dinilai dari grafik scatterplot, dimana data harus berdistribusi dengan acak dan berada di antara garis 0 (Hantono, 2017, p. 70).

Uji autokorelasi dilaksanakan melalui penganalisaan perbandingan nilai Durbin Watson yang dihasilkan menggunakan tabel Durbin Watson (Hantono, 2017, p. 67). Terbebasnya data dari gejala autokoreasi ditentukan dengan nilai DW $<\mathrm{dU}<4-\mathrm{dU}$. 
Owner: Riset \& Jurnal Akuntansi

e-ISSN : 2548-9224 |p-ISSN : 2548-7507

Volume xx Nomor xx, Bulan Tahun

DOI : https://doi.org/10.33395/owner.xxx.xxx

\section{Metode Analisis Data Penelitian}

Analisis regresi linear berganda merupakan metode analisis data pada penelitian ini, guna mengukur pengaruh diantara variabel independen dan dependen yang memakai beberapa variabel. Persamaan regresi pada penelitian ini yaitu :

$$
Y=\alpha+\beta 1 \mathrm{X} 1+\beta 2 \mathrm{X} 2+\beta 3 \mathrm{X} 3+\beta 4 \mathrm{X} 4
$$

Keterangan :
$\mathrm{Y}$
: Cash Holding
$\alpha$
Konstanta
$\beta_{1, \cdots, \beta_{4}}$
: Koefisien Regresi
$\mathrm{X}_{1} \quad$ : Cash Flow
$\mathrm{X}_{2} \quad$ : Growth Opportunity
$\mathrm{X}_{3} \quad:$ : Leverage
$\mathrm{X}_{4} \quad$ : Net Profit/LossKoefisien Determinasi

Koefisien-determinasi $\left(\mathrm{R}^{2}\right)$ dilakukan guna menilai besarnya tingkat probabilitas variabel bebas seperti cash flow, growth opportunity, leverage, dan net profit/loss dalam garis regresi variabel terikat yakni cash holding. Besarnya nilai koefisien determinasi akan berbanding lurus dengan kemampuan varian dan variabel bebas menjelaskan variabel terikat (Hantono, 2017, p. 71).

\section{Uji T}

Uji T ialah pengujian pada independent variable terhadap dependent variable untuk melihat pengaruhnya, dengan menggunakan standar signifikansi 5\% dan 10\%. Hipotesis dapat diterima bila nilai sig $<0,05$ dan 0,1 namun, hipotesis dapat ditolak bila nilai sig > 0,05 \& 0,1 (Hantono, 2017, p. 74).

Uji F

Uji F merupakan tindakan dalam memprediksi hubungan antara dependent variable dengan independent variable secara bersamaan. Pengujian ini dapat dinilai melalui perbandingan nilai $\mathrm{F}$ hitung terhadap nilai $\mathrm{F}$ tabel yang ada. Jika probabilitas $<0,05$ maka penelitian ini bisa dilanjutkan (Hantono, 2017, p. 72)

\section{Uji Asumsi Klasik}

\section{HASIL}

\section{Uji Normalitas}

Pengujian asumsi normalitas yang dilakukan pada penelitian ini tidak memenuhi syarat asumsi normalitas, sehingga dilakukan outlier sebanyak 9 data. Berikut merupakan tabel Kolmogorov Smirnov Test yang menjadi hasil dari pengujian normalitas :

Tabel 4. Uji KS

One-Sample Kolmogorov-Smirnov Test

\begin{tabular}{|c|c|c|c|}
\hline \multirow{11}{*}{$\begin{array}{l}\text { Sumber : } \\
2020\end{array}$} & & & Unstandardized Residual \\
\hline & $\mathrm{N}$ & & 99 \\
\hline & Ha & Mean & $0 \mathrm{E}-7$ \\
\hline & Normal Parameters & Std. Deviation & .11353310 \\
\hline & & Absolute & .130 \\
\hline & Most Extreme Differences & Positive & .130 \\
\hline & & Negative & -.080 \\
\hline & Kolmogorov-Smirnov Z & & 1.295 \\
\hline & Asymp. Sig. (2-tailed) & & .070 \\
\hline & a. Test distribution is Nor & & \\
\hline & b. Calculated from data. & & \\
\hline
\end{tabular}

Output SPPS 
Owner: Riset \& Jurnal Akuntansi

e-ISSN : 2548-9224 | p-ISSN : 2548-7507

Volume xx Nomor xx, Bulan Tahun

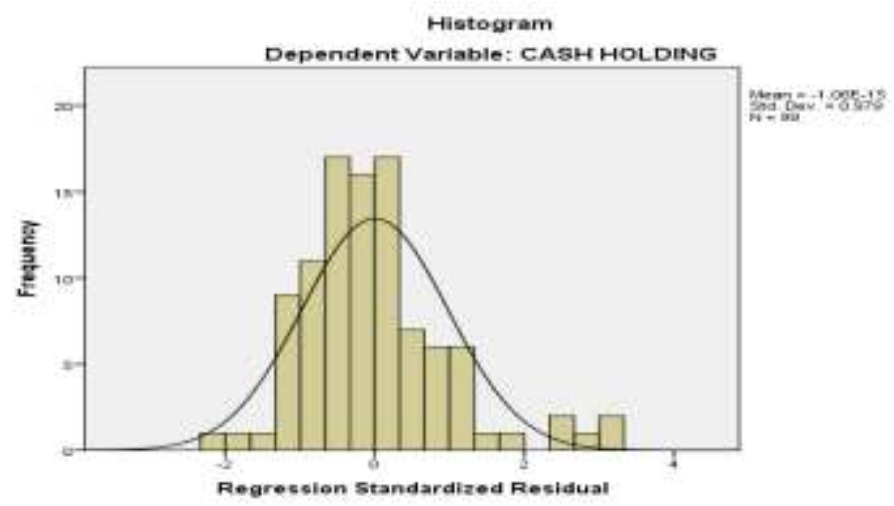

Gambar 1. Grafik Histogram Uji Normalitas

Sumber : Output SPSS 2020

Berdasarkan uji KS, diperoleh nilai Asymp Sig (2-tailed) sebesar 0,70>0,05 dimana bisa ditarik kesimpulan bahwa data sudah terdistribusi normal karena kriteria dalam pengujian Kolmogorov-Smirnov telah dipenuhi.

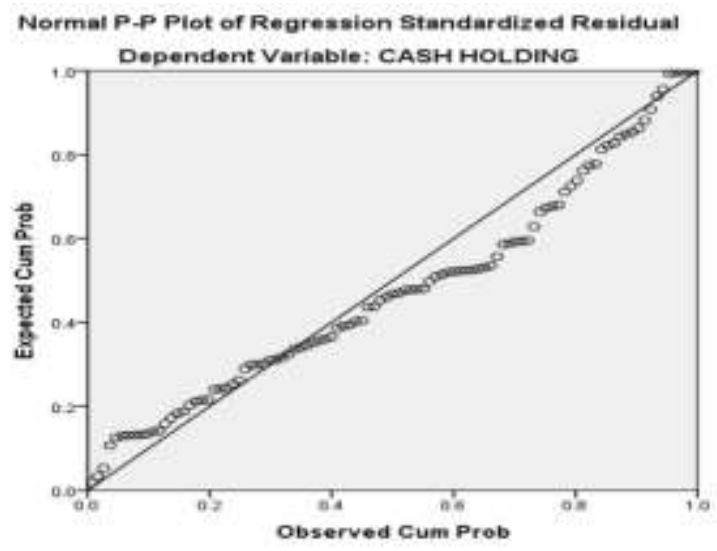

Gambar 2. Grafik Normalitas P-P Plot

Sumber : Output SPSS 2020

Gambar 1 grafik histogram pada pengujian normalitas berbentuk menyerupai lonceng serta pada gambar 2 grafik normalitas P-P Plot menunjukkan gambar dimana titik-titik mengikuti garis diagonalnya sehingga kesimpulannya ialah, data telah terdistribusi normal.

\section{Uji Multikolinearitas}

Tabel 5. Uji Multikolinearitas

Coefficients $^{\mathrm{a}}$

\begin{tabular}{|c|c|c|c|c|c|c|c|}
\hline \multirow[t]{2}{*}{ Model } & \multicolumn{2}{|c|}{$\begin{array}{l}\text { Unstandardized } \\
\text { Coefficients }\end{array}$} & \multirow{2}{*}{$\begin{array}{c}\begin{array}{c}\text { Standardized } \\
\text { Coefficients }\end{array} \\
\text { Beta }\end{array}$} & \multirow[t]{2}{*}{$\mathrm{t}$} & \multirow[t]{2}{*}{ Sig. } & \multicolumn{2}{|c|}{$\begin{array}{l}\text { Collinearity } \\
\text { Statistics }\end{array}$} \\
\hline & B & Std. Error & & & & Tolerance & VIF \\
\hline (Constant) & .205 & .045 & & 4.547 & .000 & & \\
\hline CASH FLOW & 412 & .114 & .432 & 3.618 & .000 & .468 & 2.137 \\
\hline $\begin{array}{l}\text { GROWTH } \\
\text { OPPORTUNITY }\end{array}$ & -.162 & .109 & -.129 & -1.484 & .141 & .878 & 1.139 \\
\hline
\end{tabular}


Owner: Riset \& Jurnal Akuntansi

e-ISSN : 2548-9224 |p-ISSN : 2548-7507

Volume xx Nomor xx, Bulan Tahun

DOI : https://doi.org/10.33395/owner.xxx.xxx

\begin{tabular}{|l|r|r|r|r|r|r|r|}
\hline LEVERAGE & -.338 & .078 & -.378 & -4.329 & .000 & .873 & 1.145 \\
NET PROFIT / LOSS & -.021 & .045 & -.054 & -.465 & .643 & .490 & 2.042 \\
\hline
\end{tabular}

a. Dependent Variable: CASH HOLDING

Sumber : Output SPSS 2020

Berdasarkan tampilan output pada pengujian multikolinearitas, diperoleh nilai tolerance variabel independen $\geq 0,01 \&$ variance inflation factor $(\mathrm{VIF}) \leq 10$ yang menunjukkan data ini sudah terbebas dari gejala mulitkolinearitas dan memenuhi syarat.

\section{Uji Heteroskedastisitas}

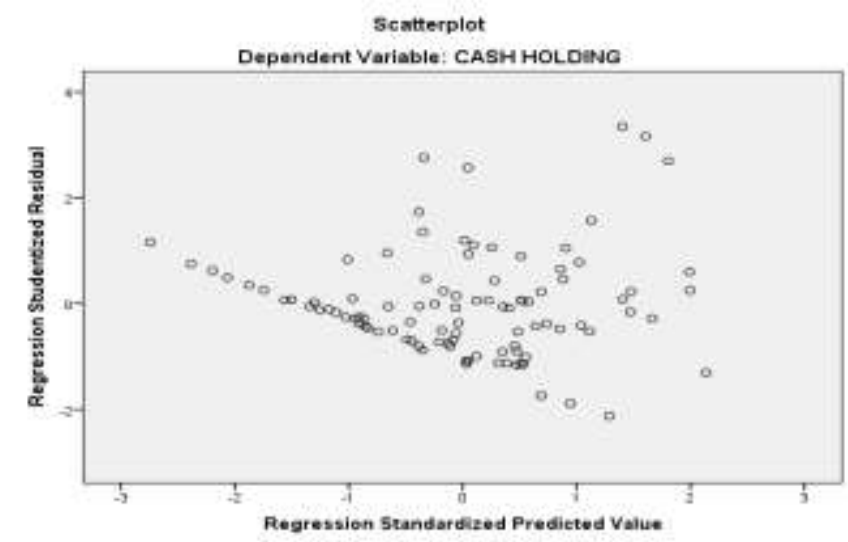

Gambar 3. Uji Heteroskedastisitas Scatterplot

Sumber : Output SPSS 2020

Grafik scatterplot pada gambar di atas, data tersebar dengan acak diantara garis 0 maka kesimpulannya ialah data terbebas dari gejala heteroskedastisitas.

Tabel 6. Uji Spearman's Rho

Correlations

\begin{tabular}{|c|c|c|c|c|c|c|c|}
\hline & & & $\begin{array}{l}\text { CASH } \\
\text { FLOW }\end{array}$ & $\begin{array}{c}\text { GROWTH } \\
\text { OPPORTUN } \\
\text { ITY }\end{array}$ & $\begin{array}{c}\text { LEVERAG } \\
\text { E }\end{array}$ & $\begin{array}{c}\text { NET } \\
\text { PROFIT / } \\
\text { LOSS }\end{array}$ & $\begin{array}{c}\text { Unstandardi } \\
\text { zed } \\
\text { Residual }\end{array}$ \\
\hline \multirow{13}{*}{$\begin{array}{l}\text { Spearma } \\
\text { n's rho }\end{array}$} & \multirow{3}{*}{$\begin{array}{l}\text { CASH } \\
\text { FLOW }\end{array}$} & Correlation & 1.000 & $.204^{*}$ & $-.241^{*}$ & $.625^{* *}$ & -.014 \\
\hline & & Sig. (2-tailed) & & .042 & .016 & .000 & .890 \\
\hline & & $\mathrm{N}$ & 99 & 99 & 99 & 99 & 99 \\
\hline & \multirow{3}{*}{$\begin{array}{l}\text { GROWTH } \\
\text { OPPORTU } \\
\text { NITY }\end{array}$} & Correlation & $.204^{*}$ & 1.000 & .124 & .120 & .021 \\
\hline & & Sig. (2-tailed) & .042 & & .221 & .237 & .835 \\
\hline & & $\mathrm{N}$ & 99 & 99 & 99 & 99 & 99 \\
\hline & \multirow{3}{*}{$\begin{array}{l}\text { LEVERAG } \\
\text { E }\end{array}$} & $\begin{array}{l}\text { Correlation } \\
\text { Coefficient }\end{array}$ & $-.241^{*}$ & .124 & 1.000 & $-.271^{* * *}$ & .077 \\
\hline & & Sig. (2-tailed) & .016 & .221 & & .007 & .447 \\
\hline & & $\mathrm{N}$ & 99 & 99 & 99 & 99 & 99 \\
\hline & \multirow{3}{*}{$\begin{array}{l}\text { NET } \\
\text { PROFIT / } \\
\text { LOSS }\end{array}$} & $\begin{array}{l}\text { Correlation } \\
\text { Coefficient }\end{array}$ & $.625^{* *}$ & .120 & $-.271^{* *}$ & 1.000 & -.089 \\
\hline & & Sig. (2-tailed) & .000 & .237 & .007 & & .379 \\
\hline & & $\mathrm{N}$ & 99 & 99 & 99 & 99 & 99 \\
\hline & $\begin{array}{l}\text { Unstandardi } \\
\text { zed }\end{array}$ & $\begin{array}{l}\text { Correlation } \\
\text { Coefficient }\end{array}$ & -.014 & .021 & .077 & -.089 & 1.000 \\
\hline
\end{tabular}


Owner: Riset \& Jurnal Akuntansi

e-ISSN : 2548-9224 |p-ISSN : 2548-7507

Volume xx Nomor xx, Bulan Tahun

DOI : https://doi.org/10.33395/owner.xxx.xxx

\begin{tabular}{|ll|r|r|r|r|r|}
\hline Residual & Sig. (2-tailed) & .890 & .835 & .447 & .379 &. \\
& $\mathrm{~N}$ & 99 & 99 & 99 & 99 & 99 \\
\hline
\end{tabular}

*. Correlation is significant at the 0.05 level (2-tailed).

**. Correlation is significant at the 0.01 level (2-tailed).

Sumber : Output SPSS 2020

Pada penelitian ini, penguji melakukan transformasi data untuk membebaskan data dari gejala heteroskedastisitas. Pengujian heteroskedastisitas ini dilakukan dengan uji Spearman's Rho dimana nilai sig semua variabel $\geq 0,05$ sehingga disimpulkan, data terhindar dari heteroskedastisitas.

\section{Uji Autokorelasi}

Tabel 7. Uji Autokorelasi

Model Summary ${ }^{b}$

\begin{tabular}{|l|r|r|r|r|r|}
\hline Model & \multicolumn{1}{|c|}{$\mathrm{R}$} & R Square & $\begin{array}{c}\text { Adjusted R } \\
\text { Square }\end{array}$ & $\begin{array}{c}\text { Std. Error of the } \\
\text { Estimate }\end{array}$ & Durbin-Watson \\
\hline 1 & $.612^{\mathrm{a}}$ & .374 & .347 & .11592 & 2.087 \\
\hline
\end{tabular}

a. Predictors: (Constant), NET PROFIT / LOSS, GROWTH OPPORTUNITY,

LEVERAGE, CASH FLOW

b. Dependent Variable: CASH HOLDING

Sumber : Output SPSS 2020

Pada penelitian ini, k (variabel independen) berjumlah 4 dan $\mathrm{n}$ (residual) adalah 99, didasarkan pada tabel durbin watson diambil nilai dU senilai 1,7575 dan dL senilai 1,5897 . Nilai durbin watson yang dihasilkan model summary adalah 2,087. Dalam uji autokorelasi, terdapat kriteria dimana apabila nilai $\mathrm{dU}<\mathrm{dW}<4$ - dU, artinya terbebas dari autokorelasi. Penelitian ini memperoleh hasil bahwa 1,7575 (dU) < 2,087 (dW) < 2,2425 (4-Du) yang menandakan bahwa penelitian sudah bebas dari terjadinya autokorelasi.

\section{Uji Hipotesis}

\section{Analisis Regresi Linear Berganda}

Tabel 8. Persamaan Analisis Regresi Linear Berganda

\section{Coefficients ${ }^{\mathrm{a}}$}

\begin{tabular}{|c|c|c|c|c|c|c|c|}
\hline \multirow[t]{2}{*}{ Model } & \multicolumn{2}{|c|}{$\begin{array}{c}\text { Unstandardized } \\
\text { Coefficients }\end{array}$} & $\begin{array}{l}\text { Standardized } \\
\text { Coefficients }\end{array}$ & \multirow[t]{2}{*}{$\mathrm{t}$} & \multirow[t]{2}{*}{ Sig. } & \multicolumn{2}{|c|}{$\begin{array}{l}\text { Collinearity } \\
\text { Statistics }\end{array}$} \\
\hline & $\mathrm{B}$ & Std. Error & Beta & & & Tolerance & VIF \\
\hline (Constant) & .205 & .045 & & 4.547 & .000 & & \\
\hline CASH FLOW & .412 & .114 & 432 & 3.618 & .000 & .468 & 2.137 \\
\hline $\begin{array}{l}\text { GROWTH } \\
\text { OPPORTUNITY }\end{array}$ & -.162 & .109 & -.129 & $1.484^{-}$ & 141 & .878 & 1.139 \\
\hline LEVERAGE & -.338 & .078 & -.378 & 4.329 & .000 & .873 & 1.145 \\
\hline NET PROFIT / LOSS & -.021 & 045 & -.054 & -.465 & 643 & .490 & 2.042 \\
\hline
\end{tabular}

a. Dependent Variable: CASH HOLDING

Sumber : Output SPSS 2020 ini, yakni :

Berdasarkan tabel 8 di atas, didapatkan persamaan regresi linear berganda pada penelitian

Cash Holding (Y) = 0,205 (a) + 0,412 Cash Flow (b1) - 0,162 Growth Opportunity (b2) - 0,338 Leverage (b3) - 0,021 Net Profit/Loss (b4) 
Owner: Riset \& Jurnal Akuntansi

e-ISSN : 2548-9224 |p-ISSN : 2548-7507

Volume xx Nomor xx, Bulan Tahun

DOI : https://doi.org/10.33395/owner.xxx.xxx

\section{Koefisien Determinasi}

Tabel 9. Uji Koefisien Determinasi

Model Summary ${ }^{b}$

\begin{tabular}{|l|r|r|r|r|r|}
\hline Model & \multicolumn{1}{|c|}{$\mathrm{R}$} & $\mathrm{R}$ Square & $\begin{array}{c}\text { Adjusted R } \\
\text { Square }\end{array}$ & $\begin{array}{c}\text { Std. Error of the } \\
\text { Estimate }\end{array}$ & Durbin-Watson \\
\hline 1 & $.612^{\mathrm{a}}$ & .374 & .347 & .11592 & 2.087 \\
\hline
\end{tabular}

a. Predictors: (Constant), NET PROFIT / LOSS, GROWTH OPPORTUNITY,

LEVERAGE, CASH FLOW

b. Dependent Variable: CASH HOLDING

Sumber : Output SPSS 2020

Besarnya dampak yang diterima variabel $\mathrm{Y}$ melalui variabel $\mathrm{X}$ bisa terlihat dari nilai Adjusted R Square adalah 0,347 atau 34,7\% yang artinya variabel independen (cash flow, growth opportunity, leverage, dan net profit/loss) mempengaruhi variabel dependen (cash holding) sebanyak $34,7 \%$ dan $65,3 \%$ terpengaruh dengan variabel lainnya selain dari penelitian ini.

Uji F

Tabel 10. Uji F

ANOVA $^{\mathrm{a}}$

\begin{tabular}{|rl|r|r|r|r|r|}
\hline Model & & Sum of Squares & Df & Mean Square & F & \multicolumn{1}{c|}{ Sig. } \\
\hline \multirow{2}{*}{1} & Regression & .755 & 4 & .189 & 14.038 & $.000^{\mathrm{b}}$ \\
& Residual & 1.263 & 94 & .013 & & \\
& Total & 2.018 & 98 & & & \\
\hline
\end{tabular}

a. Dependent Variable: CASH HOLDING

b. Predictors: (Constant), NET PROFIT / LOSS, GROWTH OPPORTUNITY, LEVERAGE, CASH FLOW

Sumber : Output SPSS 2020

Berdasarkan data penelitian ini, didapatkan nilai df $1=4 \&$ df $2=94$, sehingga nilai $\mathrm{f}$ tabel data ini adalah senilai 2,47, nilai f hitung berdasarkan tabel anova adalah 14,038, dan nilai sig sebanyak $0,000<0,05$ sehingga dinyatakan variabel independen secara simultan memberikan pengaruh terhadap variabel dependen.

Uji T

Tabel 11. Uji T

Coefficients $^{\mathrm{a}}$

\begin{tabular}{|c|c|c|c|c|c|c|c|}
\hline \multirow[t]{2}{*}{ Model } & \multicolumn{2}{|c|}{$\begin{array}{l}\text { Unstandardized } \\
\text { Coefficients }\end{array}$} & $\begin{array}{l}\text { Standardized } \\
\text { Coefficients }\end{array}$ & \multirow[t]{2}{*}{$\mathrm{t}$} & \multirow[t]{2}{*}{ Sig. } & \multicolumn{2}{|c|}{$\begin{array}{l}\text { Collinearity } \\
\text { Statistics }\end{array}$} \\
\hline & B & Std. Error & Beta & & & Tolerance & VIF \\
\hline (Constant) & .205 & .045 & & 4.547 & .000 & & \\
\hline CASH FLOW & .412 & .114 & .432 & 3.618 & .000 & .468 & 2.137 \\
\hline $1 \begin{array}{l}\text { GROWTH } \\
\text { OPPORTUNITY }\end{array}$ & -.162 & .109 & -.129 & -1.484 & .141 & .878 & 1.139 \\
\hline LEVERAGE & -.338 & .078 & -.378 & -4.329 & .000 & .873 & 1.145 \\
\hline NET PROFIT / LOSS & -.021 & .045 & -.054 & -.465 & 643 & .490 & 2.042 \\
\hline
\end{tabular}

a. Dependent Variable: CASH HOLDING

Sumber : Output SPSS 2020

Pada cash flow, nilai t hitung bernilai positif yaitu 3,618, dimana nilai t hitung $>\mathrm{t}$ tabel, yaitu 3,618 $>1,98552$ dan nilai sig 0,000 < 0,05 sehingga dapat diartikan, cash flow berpengaruh positif dan signifikan terhadap cash holding. Pada growth opportunity, nilai t hitung bernilai negatif yaitu $-1,484$, dimana nilai $\mathrm{t}$ hitung $<\mathrm{t}$ tabel, yaitu 1,484 $<1,98552$ dan nilai sig 0,141 > 0,05 sehingga dapat diartikan, growth opportunity tidak berpengaruh dan tidak signifikan 
terhadap cash holding. Pada leverage, nilai t hitung bernilai negatif yaitu $-4,329$, dimana nilai $\mathrm{t}$ hitung > t tabel, yaitu 4,329 > 1,98552 dan nilai sig 0,000 < 0,05 sehingga dapat diartikan, leverage berpengaruh negatif dan signifikan terhadap cash holding. Pada net profit/loss, nilai $\mathrm{t}$ hitung bernilai negatif yaitu $-0,465$, dimana nilai $t$ hitung $<\mathrm{t}$ tabel, yaitu $0,465<1,98552$ dan nilai sig 0,643 >0,05 sehingga dapat diartikan, net profit/loss tidak berpengaruh dan tidak signifikan terhadap cash holding.

\section{Pengaruh Cash Flow terhadap Cash Holding}

\section{PEMBAHASAN}

Melalui penelitian ini diperoleh hasil bahwa cash flow berpengaruh positif dan signifikan terhadap cash holding. Hal ini didasarkan pada hasil uji $\mathrm{T}$, yang memperoleh nilai $\mathrm{t}$ hitung bernilai positif yakni 3,618 $>1.98552 \&$ nilai signifikan $0.000<0.05$. Hipotesis pertama diterima karena sejalan dengan hasil penelitian.

Hasil ini diperkuat dengan pecking order theory yang menyebutkan, industri senantiasa akan memiliki cash holding dengan nilai yang cukup besar apabila mempunyai nilai cash flow yang besar. Industri yang mempunyai nilai cash flow besar cenderung akan mendahulukan penggunaan dana internal untuk membiayai proyek baru, melunasi hutang, pembayaran dividen, dan lain sebagainya. Oleh karena itu, tingkat cash flow suatu perusahaan akan berbanding lurus dengan nilai cash holding. Penelitian (Maya Sari \& Ardian, 2019) sejalan dengan hasil penelitian ini. Akan tetapi, hasil ini bertolak belakang dengan hasil penelitian (Gunawan, 2016).

\section{Pengaruh Growth Opportunity terhadap Cash Holding}

Melalui penelitian ini diperoleh hasil bahwa growth opportunity tidak berpengaruh dan tidak signifikan terhadap cash holding. Hal ini didasarkan pada hasil uji $\mathrm{T}$, yang memperoleh nilai t hitung bernilai negatif yakni $1,485<1,98552 \&$ nilai signifikan $0,141>0,05$. Hipotesis kedua ditolak karena tidak sejalan dengan hasil penelitian.

Dapat dinyatakan bahwa pada penelitian ini, nilai peluang pertumbuhan industri/perusahaan tidak akan mempengaruhi nilai cash holding perusahaan menjadi berkurang atau bertambah dikarenakan perusahaan tidak menggunakan growth opportunity untuk pertimbangan dalam melakukan penahanan kas. Perusahaan lebih mengarahkan penggunaan kas untuk membiayai proses produksi.

Penelitian (Hengsaputri \& Bangun, 2020) sejalan dengan hasil penelitian ini. Tetapi, tidak sejalan dengan penelitian (Sari \& Hastuti, 2020).

\section{Pengaruh Leverage terhadap Cash Holding}

Melalui penelitian ini diperoleh hasil bahwa leverage berpengaruh negatif dan signifikan terhadap cash holding. Hal ini didasarkan pada hasil uji $\mathrm{T}$, yang memperoleh nilai t hitung bernilai negatif yakni 4,329 > 1,98552 \& nilai sig $0,000<0,05$. Hasil penelitian ini bertolak belakang dengan hipotesis ketiga, yang berarti H3 ditolak.

Hal yang mendasari hasil penelitian ini adalah besarnya nilai leverage disebabkan oleh industri yang menyimpan dana dengan tingkat yang rendah karena perusahaan memiliki kewajiban beserta bunga hutang yang harus diselesaikan. Alasan lainnya karena perusahaan membeli aset lainnya secara kredit untuk mendapatkan keuntungan yang lebih besar, sehingga perusahaan menyimpan cash holding dalam jumlah yang rendah. Hasil ini di dukung oleh (Saputri \& Kuswardono, 2019) dan (Suherman, 2017) namun, tidak sejalan dengan hasil penelitian (Dwitama, 2017).

\section{Pengaruh Net Profit terhadap Cash Holding}

Melalui penelitian ini diperoleh hasil bahwa tidak adanya pengaruh yang signifikan oleh net profit terhadap cash holding. Kesimpulan ini dikarenakan nilai t hitung bernilai negatif yaitu $0,465<1,98552 \&$ nilai sig $0,643>0,05$. Hipotesis keempat ditolak karena tidak sejalan dengan hasil penelitian.

Perusahaan yang memperoleh laba yang besar cenderung menyimpan cash holding dengan nilai yang besar. Akan tetapi, perusahaan yang menjadi objek dalam penelitian ini 
sebagian besar tidak menetapkan net profit/loss sebagai tolak ukur dalam penentuan nilai optimal cash holding perusahaan. Perusahaan lebih memfokuskan laba yang diperoleh untuk dikonversikan ke dalam bentuk aset lancar persediaan untuk menunjang proses produksi daripada dikonversi ke dalam bentuk kas. Hasil penelitian ini tidak sejalan dengan hasil penelitian (Humendru \& Pangaribuan, 2018).

\section{Pengaruh Cash Flow, Growth Opportunity, Leverage, dan Net Profit/Loss terhadap Cash Holding}

Berdasarkan hasil uji $\mathrm{F}$, dengan nilai df (n1) yaitu 4 dan df (n2) yaitu 94, maka nilai $\mathrm{f}$ tabel yang dihasilkan adalah 2,47 dan nilai f hitung sebesar 14,038. Dari penelitian ini didapatkan hasil bahwa terdapat pengaruh cash flow, growth-opportunity, leverage, dan net profit/loss secara bersama-sama terhadap cash holding pada perusahaan sektor consumer goods yang terdaftar di IDX tahun 2017-2019. Hal ini dilihat melalui uji F, dimana nilai $\mathrm{f}$ hitung pada tabel anova senilai $14,038 \&$ nilai signifikan $0,000<0,05$. Hipotesis kelima diterima karena sejalan dengan hasil penelitian.

\section{KESIMPULAN}

Cash flow berpengaruh positif dan signifikan terhadap cash holding. Hasil tersebut dapat dilihat melalui uji $\mathrm{T}$, dimana $\mathrm{t}$ hitung bernilai positif, sebesar 2,902 dimana $\mathrm{t}$ hitung $>\mathrm{t}$ tabel, yaitu $2,902>1,987933$ dan nilai sig $0,005<0,05$. Growth opportunity tidak berpengaruh dan tidak signifikan terhadap cash holding. Hasil tersebut dapat dilihat melalui uji $\mathrm{T}$, dimana $\mathrm{t}$ hitung bernilai negatif sebesar $-0,532$ dimana $t$ hitung $<\mathrm{t}$ tabel, yaitu $0,532<1,987933$ dan nilai sig $0,596>0,05$. Leverage berpengaruh negatif dan signifikan terhadap cash holding. Hasil tersebut dapat dilihat melalui uji $\mathrm{T}$, dimana $\mathrm{t}$ hitung bernilai negatif sebesar $-3,962$ dimana $\mathrm{t}$ hitung $>\mathrm{t}$ tabel, yaitu 3,962 >1,987933 dan nilai sig $0,000<0,05$. Net profit/loss tidak berpengaruh dan tidak signifikan terhadap cash holding. Hasil tersebut dapat dilihat melalui uji $\mathrm{T}$, dimana t hitung bernilai positif sebesar 0,212 dimana $t$ hitung $<\mathrm{t}$ tabel, yaitu $0,212<1,98793$ dan nilai sig 0,832 $>0,05$. Cash flow, growth opportunity, leverage, dan net profit/loss berpengaruh secara simultan dan signifikan terhadap cash holding. Hasil tersebut dapat dilihat melalui uji $F$, dimana nilai $\mathrm{f}$ hitung pada tabel anova sebesar 10,795 dan nilai signifikan $0,000<0,05$.

\section{REFERENSI}

Alicia, R., Putra, J., Fortuna, W., Felin, F., \& Purba, M. I. (2020). Pengaruh Growth Opportunity, Leverage dan Firm Size terhadap Cash Holding Perusahaan Properti dan Real Estate. Owner (Riset Dan Jurnal Akuntansi), 4(2), 322. https://doi.org/10.33395/owner.v4i2.219

Andika, M. S. (2017). Analisis Pengaruh Cash Convertion Cycle, Leverage, Net Working Capital, dan Growth Opportunity Terhadap Cash Holdings Perusahaan (Studi Kasus Pada Perusahaan Industri Barang Konsumsi di Bursa Efek Indonesia Periode 2010 - 2015). JOM Fekon, 4(1), 1479-1493.

Angelia, M., \& Dwimulyani, S. (2019). Profitability, Leverage Dan Firm Size Mempengaruhi Cash Holding Dengan Tax Avoidance Sebagai Variabel Intervening. Jurnal Sosial Dan Humaniora, 2(46), 1-11.

Dwitama, F. (2017). Analisis Pengaruh Leverage,Cash conversion cycle,Cash flow terhadap cash holding perusahaan. Jurnal Manajemen.

Ghozali, I. (2016). Aplikasi Analisis Multivariate Dengan Program IBM SPSS 23 (8th ed.).

Semarang: Badan Penerbit Universitas Diponegoro.

Gunawan, R. (2016). PENGARUH GROWTH OPPORTUNITY, NET WORKING CAPITAL DAN CASH FLOW TERHADAP CASH HOLDING. Jurnal Akuntansi, 4(1).

Hantono. (2017). Konsep Analisa Laporan Keuangan dengan Pendekatan Rasio dan SPSS. Yogyakarta: Deepublish.

Hasana, E. R. (2019). ANALISIS PENGARUH CASH CONVERSION CYCLE, MODAL KERJA BERSIH, GROWTH OPPORTUNITY DAN CAPITAL EXPENDITURE TERHADAP CASH HOLDING ARTIKEL. Jurnal Akuntansi.

Hengsaputri, J. A., \& Bangun, N. (2020). Pengaruh Growth Opportunity, Net Working Capital 
dan Cash Flow Terhadap Cash Holding. Jurnal Multparadigma Akuntansi Tarumanegara, 2(1), 1343-1352.

Humendru, A., \& Pangaribuan, J. (2018). Faktor-Faktor Yang Mempengaruhi Kebijakan Cash Holding. 4(1), 1-22.

Kariyoto. (2018). Manajemen Keuangan: Konsep dan Implementasi. Malang: UB Press.

Kartikahardi, H., Sinaga, U. ., Wahyuni, T. e, Siregar, V. S., \& Syamsul, M. (2017). PSAK No.2 Akuntansi Keuangan tentang Laporan Arus Kas. Ikatan Akuntansi Indonesia.

Maya Sari, D., \& Ardian, A. (2019). Cash Holding, Cash Flow dan Profitability: Studi pada Perusahaan Manufaktur yang Terdaftar di Bursa Efek Indonesia. Jurnal Dinamika Akuntansi Dan Bisnis, 6(1), 29-38. https://doi.org/10.24815/jdab.v6i1.12142

Powell, G. E. (2018). The financial determinants of corporate cash holdings for Indonesian firms. Academy of Accounting and Financial Studies Journal, 22(1).

Saputri, E., \& Kuswardono, A. (2019). Pengaruh Profitabilitas, Leverage, Firm Size, dan Growth Opportunity Terhadap Cash Holding Perusahaan (Studi Kasus Perusahaan Manufaktur yang Terdaftar Pada Bursa Efek Indonesia Periode Tahun 2013-2017). Management, and Industry (JEMI), 2(2), 91-104.

Sari, V. P., \& Hastuti, R. T. (2020). Pengaruh Net Working Capital, Leverage,Growth Opportunity, dan Profitabilitas Terhadap Cash Holding. Jurnal Multiparadigma Akuntansi Tarumanagara, 2, 1559-1567.

Sethi, M., \& Swain, R. K. (2019). Determinants of Cash Holdings: A Study of Manufacturing Firms in India. International Journal of Management Studies, VI(2(2)), 11. https://doi.org/10.18843/ijms/v6i2(2)/02

Shabbir, M., Haider Hashmi, S., \& Mujtaba Chaudhary, G. (2016). Determinants of corporate cash holdings in Pakistan. International Journal of Organizational Leadership, 5(1), 50-62. https://doi.org/10.33844/ijol.2016.60263

Silaban, P., \& Siahaan, R. (2016). Manajemen Keuangan Teori dan Aplikasi. Medan: Universitas HKBP Nomensen.

Simanjuntak, F. S., \& Wahyudi, A. S. (2020). Faktor- Faktor Yang Mempengaruhi Cash Holding. Jurnal Riset Akuntansi, 12(1), 25-41. https://doi.org/10.34208/jba.v19i1 a-1.138

Sugiyono. (2017). Metode Penelitian Kuantitatif Kualitatif dan R\&D. Bandung: PT. Alfabeta.

Suherman, S. (2017). Faktor-Faktor Yang Mempengaruhi Cash Holdings Perusahaan Di Bursa Efek Indonesia. Jurnal Manajemen, 21(3), 336. https://doi.org/10.24912/jm.v21i3.255 